\title{
THE STORAGE ABILITY OF LAMB'S LETTUCE CULTIVATED IN THE GREENHOUSE UNDER LED OR HPS LAMPS
}

\author{
Anna KOŁTON ${ }^{1}$, Renata WOJCIECHOWSKA ${ }^{1}$, Olga DŁUGOSZ-GROCHOWSKA ${ }^{1}$, \\ Wojciech GRZESIAK ${ }^{2}$ \\ ${ }^{1}$ Institute of Plant Biology and Biotechnology, Faculty of Horticulture, \\ University of Agriculture in Kraków, al. 29 Listopada 54, 31-425 Cracow, Poland \\ ${ }^{2}$ Institute of Electron Technology, al. Lotników 32/46, 02-668 Warsaw, Poland
}

Received: August 8, 2014; Accepted: November 11, 2014

\begin{abstract}
Leafy vegetables are the source of many valuable components like vitamins, minerals and phenolic compounds as antioxidants. Chlorophyll derivatives have antioxidant and anticarcinogenic activity, or may even act as signalling molecules in organisms. However, during the storage of the leafy vegetables in the cold and darkness, numerous biochemical changes usually occurs, demonstrated as the breakdown of chlorophyll. Storage ability of plants depends to some extent on the conditions under which plants grew. Lamb's lettuce plants were grown in the greenhouse in different light regimes - emitted with sodium (HPS-control) and LED lamps ( $100 \%$ red, $90 \%$ red $+10 \%$ blue, $70 \%$ red $+30 \%$ blue and $50 \%$ red $+50 \%$ blue light). The intensity of radiation at the height of the leaves of the plants was the same in every treatment. After harvesting, the plants were stored at the temperature of $5^{\circ} \mathrm{C}$ and high humidity in plastic bags. The analyses of the material were done four times: after harvest and three times during storage at weekly intervals. Fresh weight lost, dry matter, phenolics and chlorophyll content were analysed. Additionally, the fluorescence of chlorophyll $a$ was carried out. Changes in plant fresh weight and dry matter content during storage did not depend on the lighting used during cultivation. After 3 weeks of storage, higher value of indicator of the vitality of PSII (PI ABS $_{-}$Performance Index) was noticed in leaves treated with higher red light intensity during cultivation $(100 \%, 90 \%$ and $70 \%$ red). LED lamps, which emitted $100 \%$ and $90 \%$ red light, enhanced concentration of total phenolics in lamb's lettuce leaves. Light of HPS lamps decreased radical scavenging activity in leaves. Quality and usefulness of plants produced under LED lamps was just as good as those grown under HPS lamps.
\end{abstract}

Key words: Valerianella locusta, health-promoting substances, leaf senescence, chlorophyll fluorescence

\section{INTRODUCTION}

Valerianella locusta Laterr. Em Betcke (Valerianaceae) is a delicate leafy vegetable, which is an excellent source of many health-promoting compounds such as vitamins, minerals, folic acid and others, therefore it can diversify the human diet in winter months (Péron \& Rees 1998; MartyniakPrzybyszewska 2005). However, in autumn-winter season in Poland, it is difficult to produce a high quantity and quality yield of vegetables without supplemental lighting. High-pressure sodium lamps
(HPS) are the most common artificial source of light used in crop production. Due to the high energy consumption HPS lamps are being replaced by alternative sources, including LED lamps (Massa et al. 2008). Research on the use of diode light in plant cultures has been carried out since the mid-80s of the twentieth century (Morrow 2008). Today, modern SSL LED technologies (Solid State Lighting Light Emitting Diode) are increasingly used in various branches of horticulture, including greenhouse production (Trouwborst et al. 2010; Klamkowski et al. 2012). It is well known that the presence and the 
quality of phytochemical components depend on a light factor. Several studies have been reported that blue and red LEDs light might be useful for improving antioxidant properties of plants (Jung et al. 2013). Hogewoning et al. (2010) studied photosynthesis in Cucumis sativus leaves grown under LED light with different ratio blue/red, and showed, that in the blue range $0-50 \%$ photosynthetic capacity $\left(A_{\max }\right)$ was gradually increasing what was associated with increase of nitrogen and chlorophyll content per unit of leaf area. Hence, it would be interesting to investigate the effect of supplementary red + blue LED lighting (of different ratio) on some prohealthy parameters and chlorophyll content in Valerianella locusta leaves. Many studies concerning quality parameters of vegetables are carried out on the final product immediately after harvesting. However, content and composition of nutrients can be strongly modified during storage (Wills et al. 1998). Leafy vegetables are especially sensitive to storage conditions, which accelerate the senescence processes. The most visual sign of senescence is leaf yellowing caused by chlorophyll degradation. Fluorescence of chlorophyll is a good indicator of leaf senescence, because it allows to evaluate the physiological state of tissue even before visual symptoms of aging (Lichtenthaler \& Babani 2004). Li \& Kubota (2009) and Samuoliene et al. (2012) postulated that supplemental LED light could be used to enhance growth and nutritional value of baby leaf lettuce.

The aim of this study was to examine the effect of supplemental LED lighting (red + blue) used in Valerianella locusta greenhouse cultivation on the changes in phenols and chlorophylls content as well as on fresh weight lost and dry matter content during 3 weeks storage in temperature $5^{\circ} \mathrm{C}$. Additionally, the fluorescence measurements of chlorophyll $a$ were carried out.

\section{MATERIALS AND METHODS}

Experiment was carried out in the greenhouse at Faculty of Horticulture, Agricultural University in Krakow. Valerianella locusta Laterr. Em Betcke 'Nordhollandse' was studied. Seeds of the lamb's lettuce were sown twice into peat substrate (Klassmann KTS-2) on 1st October and 13th December
2013, for autumn and winter production. In each term, 10 days after sowing the supplemental lighting was implemented ( $16 \mathrm{~h}$ day $/ 8 \mathrm{~h}$ night). Five experimental light treatments (320 plants each) were studied. The following treatments using Solid State Lighting Light Emitting Diodes (SSL LED) lamps $(100 \mathrm{~W})$ emitting: $1.100 \%$ red, $2.90 \%$ red $+10 \%$ blue, $3.70 \%$ red $+30 \%$ blue and $4.50 \%$ red $+50 \%$ blue light were tested. Light was emitted by Osram OSLON SSL-80 series LED diodes: hyper red (660$670 \mathrm{~nm})$ and deep blue $(430-440 \mathrm{~nm})$ placed under the lens of $30^{\circ}$ beam angle. LED lamps were placed at a distance of 50-60 cm above plants. In the fifth treatment, sodium lamp (600W) as a control was used (Elektro Valo Oy, Lady bird, Netafim Ltd.). HPS lamps were placed at a distance of $100-110 \mathrm{~cm}$ above plants. In all treatments during artificial lighting, photosynthetic photon flux density at the plant level was $200 \mu \mathrm{mol} \cdot \mathrm{m}^{-2} \cdot \mathrm{s}^{-1}$. For the measurement of the photosynthetic photon flux density, light quantum sensor LI-250 equipped with a probe LI-190 SA was used. Plants were harvested on 6th December 2013 in autumn and $21^{\text {st }}$ February 2014 in winter production.

The whole rosettes of lamb's lettuce were collected in the morning and transferred to the laboratory. Taken analyses were indicated as term 0 . The remaining part of the material was put into bags (each treatment in four tight polyethylene bags), weighed and transferred to a refrigerator (temperature $5{ }^{\circ} \mathrm{C}$, darkness). After 1 week the material was pooled, weighed and analyses were performed as a term 1 . The procedure was repeated after 2 and 3 weeks of storage. In each of the four terms, the measurements of the fluorescence of chlorophyll $a$ were made with Handy Pea fluorymeter (Hansatech Instruments Ltd. UK). Before the measurements, leaves were dark adapted for $30 \mathrm{~min}$. The measurements were carried out with saturation radiation of $1500 \mu \mathrm{mol} \cdot \mathrm{m}^{-2} \cdot \mathrm{s}^{-1}$ for $1 \mathrm{~s}$. Two parameters of chlorophyll $a$ fluorescence are presented in this paper: maximum quantum efficiency of photosystemII $(\mathrm{Fv} / \mathrm{Fm})$ and indicator of the vitality of PSII ( $\mathrm{PI}_{\mathrm{ABS}}$ - Performance Index) (Strasser et al. 2004). The content of total phenolic compounds and the groups of phenylpropanoids, flavonols and anthocyanins were analysed with spectrophotometric method 
according to Fukumoto \& Mazza (2000). Chlorogenic acid, caffeic acid and quercetin were used as the standards for total phenols, phenylpropanoids and flavonols, respectively. Anthocyanin content was expressed as the cyanidin, according to its molar extinction. Concentrations of phenols were calculated and expressed in mg of standards per $100 \mathrm{~g}$ of fresh tissue. The concentration of chlorophylls and total carotenoids were determined in acetone extracts according to Wellburn (1994). Dry weight content of studied objects was also analysed. The ability of the tested plants to scavenge 2,2-diphenyl1-picrylhydrazyl (DPPH) free radicals was measured in methanol extracts as in Pekkarinen et al. (1999). In addition, loss of plant fresh weight after successive weeks of storage was calculated.

All chemical analyses were performed in triplicate or quadruplicate. Analysis of the fluorescence of chlorophyll $a$ was performed in 10 replicates. The results were statistically verified with STATISTICA10. Means were compared using one-way ANOVA module. Following the rejection of the null hypothesis of equality of means, the post-hoc LSD-Fisher test was used to determine the differences between means. All analyses were made at significance level $\alpha=0.05$.

\section{RESULTS}

Two series of the experiment were performed: in autumn and winter. Because of the similarity of dependencies obtained in both series (data not shown), the presented results include an averages of all measurements of two series of experiments.

During storage, the decrease of plant fresh weight was observed (Table 1) but no significant differences were found between light treatments in each term of analyses. A similar dependence of dry matter content on experimental factors was stated (data not presented).

Plants obtained at different light treatment had similar Fv/Fm parameters in each term of study (data not presented), but gradually decrease of $\mathrm{Fv} / \mathrm{Fm}$ was observed during storage, similarly $\mathrm{PI}_{\mathrm{ABS}}$ value decreased with time (Table 2). Interestingly, during the third term of measurements higher intensity of red light before harvest $(100 \%, 90 \%$ and $70 \%$ red) ensured a higher value of $\mathrm{PI}_{\mathrm{ABS}}$ index (Fig. 1, Table 2).

Table 1. Fresh weight loss (\%) of lamb's lettuce leaves during storage $(n=8)$; given are means of two repetitions of the experiment, in autumn and winter

\begin{tabular}{lccc}
\hline & \multicolumn{3}{c}{ Weight loss (\%) } \\
\cline { 2 - 4 } Treatment & $\begin{array}{c}\text { After } \\
1 \text { week } \\
\text { of storage }\end{array}$ & $\begin{array}{c}\text { After } \\
\text { 2 weeks } \\
\text { of storage }\end{array}$ & $\begin{array}{c}\text { After } \\
\text { of weeks } \\
\text { of storage }\end{array}$ \\
\hline 100\% RED & $0.44 \mathrm{a}^{*}$ & $0.86 \mathrm{a}$ & $1.11 \mathrm{a}$ \\
$90 \% \mathrm{RED}$ & $0.81 \mathrm{a}$ & $0.57 \mathrm{a}$ & $1.80 \mathrm{a}$ \\
$70 \% \mathrm{RED}$ & $0.85 \mathrm{a}$ & $0.78 \mathrm{a}$ & $1.37 \mathrm{a}$ \\
$50 \% \mathrm{RED}$ & $0.76 \mathrm{a}$ & $1.12 \mathrm{a}$ & $1.39 \mathrm{a}$ \\
HPS & $0.74 \mathrm{a}$ & $0.89 \mathrm{a}$ & $1.48 \mathrm{a}$ \\
\hline Mean & $0.72 \mathrm{~A} * *$ & $0.84 \mathrm{~A}$ & $1.43 \mathrm{~B}$ \\
\hline
\end{tabular}

*Small letters indicate homogenous groups separated with $\alpha=0.05$ in columns

**Capital letters indicates homogenous groups separated with $\alpha=.05$ in line

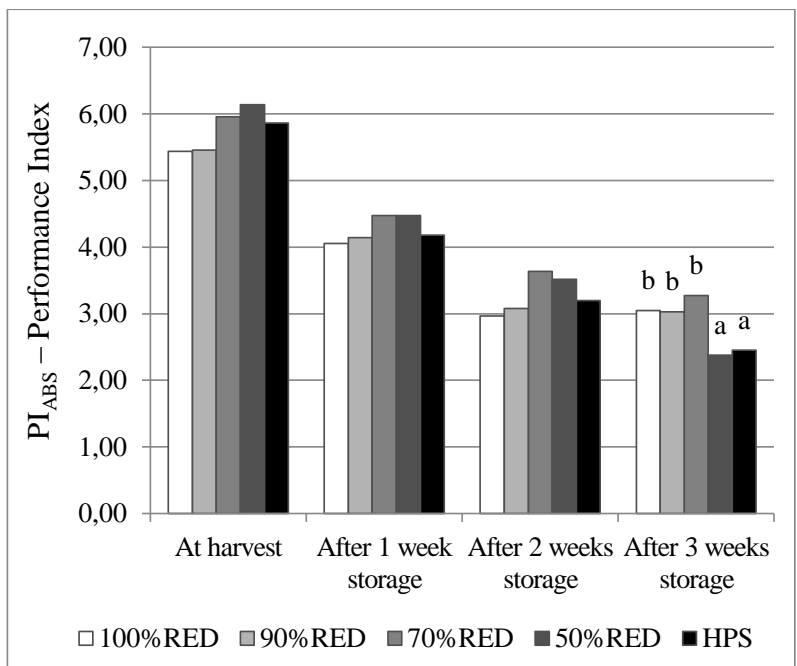

Fig. 1. Indicator of the vitality of PSII $\left(\mathrm{PI}_{\mathrm{ABS}}-\right.$ Performance Index) in lamb's lettuce leaves during experiment $(n=20)$; given are means from two repetitions of experiment, in autumn and winter. Letters indicate homogenous groups separated with $\alpha=0.05$ for each term separately, lack of letters indicates no differences 
Table 2. Maximum quantum efficiency of photosystem II $(\mathrm{Fv} / \mathrm{Fm})$ and indicator of the vitality of PSII $\left(\mathrm{PI}_{\mathrm{ABS}}-\mathrm{Per}-\right.$ formance Index) of lamb's lettuce leaves during experiment $(n=100)$, given are means from two repetitions of experiment

\begin{tabular}{lcl}
\hline Treatment & $\mathrm{Fv} / \mathrm{Fm}$ & $\mathrm{PI}_{\mathrm{ABS}}$ \\
\hline At harvest & $0.837 \mathrm{~d}^{*}$ & $5.77 \mathrm{~d}$ \\
After 1 week storage & $0.830 \mathrm{c}$ & $4.26 \mathrm{c}$ \\
After 2 weeks storage & $0.819 \mathrm{~b}$ & $3.28 \mathrm{~b}$ \\
After 3 weeks storage & $0.812 \mathrm{a}$ & $2.83 \mathrm{a}$ \\
\hline
\end{tabular}

*Letters indicate homogenous groups separated with $\alpha=0.05$ in columns

Lamb's lettuce leaves grown under HPS lamps contained less phenolics (total) than those grown under LED lamps emitted 100\% RED and 90\% RED light (Fig. 2), but significant influence was observed only for $90 \%$ RED ones. Two other LED light treatments did not influence the concentration of phenolic compounds in comparison to control. Accumulation of phenylpropanoids was observed in leaves grown at $100 \%$ and $90 \%$ RED compared to HPS ones. Flavonols and anthocyanins concentrations were similar in all treatments. Radical scavenging activity was the lowest in the leaves harvested from HPS lamps. Significant increase of RSA was observed in leaves lightened with $100 \%$, 90\% and 50\% RED LED lamps.
Leaves of lamb's lettuce are a source of dietary chlorophylls and carotenoids. Unfortunately, chlorophylls gradually decomposed during long storage, but the carotenoid content remained unchanged (Table 3). A light composition during plants growth did not affect the content of pigments at storage.

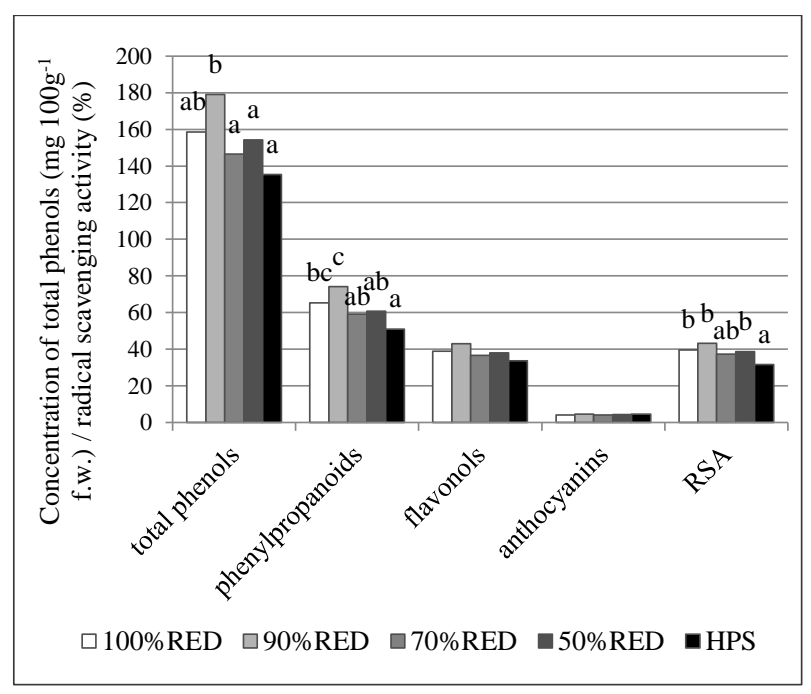

Fig. 2. Content of total phenols and groups: phenylpropanoids, flavonols and anthocyanins (mg.100 $\mathrm{g}^{-1}$ f.w.) and also radical scavenging activity (RSA) with DPPH radical $(\%)$ of lamb's lettuce leaves during experiment $(n=20-24)$; given are means from two repetitions of the experiment: in autumn and winter. Letters indicate homogenous groups separated with $\alpha=0.05$ for each parameter separately. Lack of letters indicates no differences.

Table 3. Total chlorophylls and carotenoids contents $\left(\mathrm{mg} \cdot \mathrm{g}^{-1} \mathrm{f} . \mathrm{w}\right.$.) in lamb's lettuce leaves during storage $(\mathrm{n}=6)$; given are means from two repetitions of the experiment: in autumn and winter

\begin{tabular}{lcccccccc}
\hline & \multicolumn{3}{c}{ Total chlorophylls $\left(\mathrm{mg} \cdot \mathrm{g}^{-1} \mathrm{f}\right.$.w.) } & \multicolumn{3}{c}{ Total carotenoids $\left(\mathrm{mg} \cdot \mathrm{g}^{-1} \mathrm{f} . \mathrm{w}.\right)$} \\
\cline { 2 - 9 } Treatment & $\begin{array}{c}\text { At } \\
\text { harvest }\end{array}$ & $\begin{array}{c}\text { After 1 } \\
\text { week stor- } \\
\text { age }\end{array}$ & $\begin{array}{c}\text { After } 2 \\
\text { weeks } \\
\text { storage }\end{array}$ & $\begin{array}{c}\text { After } 3 \\
\text { weeks } \\
\text { storage }\end{array}$ & $\begin{array}{c}\text { At } \\
\text { harvest }\end{array}$ & $\begin{array}{c}\text { After 1 } \\
\text { week } \\
\text { storage }\end{array}$ & $\begin{array}{c}\text { After } 2 \\
\text { weeks } \\
\text { storage }\end{array}$ & $\begin{array}{c}\text { After } 3 \\
\text { weeks } \\
\text { storage }\end{array}$ \\
\hline $100 \%$ RED & $1.033 \mathrm{a}^{*}$ & $1.060 \mathrm{a}$ & $0.951 \mathrm{a}$ & $0.959 \mathrm{a}$ & $0.180 \mathrm{a}$ & $0.187 \mathrm{a}$ & $0.186 \mathrm{a}$ & $0.203 \mathrm{a}$ \\
$90 \% \mathrm{RED}$ & $0.999 \mathrm{a}$ & $1.077 \mathrm{a}$ & $1.025 \mathrm{a}$ & $1.011 \mathrm{a}$ & $0.185 \mathrm{a}$ & $0.193 \mathrm{a}$ & $0.198 \mathrm{a}$ & $0.208 \mathrm{a}$ \\
$70 \% \mathrm{RED}$ & $1.164 \mathrm{a}$ & $1.019 \mathrm{a}$ & $1.048 \mathrm{a}$ & $1.086 \mathrm{a}$ & $0.209 \mathrm{a}$ & $0.198 \mathrm{a}$ & $0.205 \mathrm{a}$ & $0.215 \mathrm{a}$ \\
$50 \% \mathrm{RED}$ & $1.086 \mathrm{a}$ & $1.125 \mathrm{a}$ & $0.986 \mathrm{a}$ & $0.930 \mathrm{a}$ & $0.200 \mathrm{a}$ & $0.206 \mathrm{a}$ & $0.195 \mathrm{a}$ & $0.198 \mathrm{a}$ \\
$\mathrm{HPS}$ & $1.128 \mathrm{a}$ & $1.032 \mathrm{a}$ & $1.030 \mathrm{a}$ & $0.863 \mathrm{a}$ & $0.202 \mathrm{a}$ & $0.189 \mathrm{a}$ & $0.201 \mathrm{a}$ & $0.187 \mathrm{a}$ \\
\hline Mean & $1.082 \mathrm{C} * *$ & $1.062 \mathrm{BC}$ & $1.008 \mathrm{AB}$ & $0.970 \mathrm{~A}$ & $0.195 \mathrm{~A}$ & $0.194 \mathrm{~A}$ & $0.197 \mathrm{~A}$ & $0.202 \mathrm{~A}$ \\
\hline
\end{tabular}

*Small letters indicate homogenous groups separated with $\alpha=0.05$ in column

**Capital letters indicate homogenous groups separated with $\alpha=0.05$ in line for each parameter separately 


\section{DISCUSSION}

Phenolic compounds are considered as very effective antioxidants. However, among this large group, compounds with high and low antioxidant properties can be identified. Flavonols and anthocyanins are considered as the most effective antioxidants due to the large quantity of $\mathrm{OH}$ groups and double bonds in molecules (Michalak 2006). The contents of these two groups of phenols were similar in all tested plants regardless of light conditions during growth. However, different abilities to scavenge DPPH free radicals between the tested objects were demonstrated. According to Sharma \& Bhat (2009), this may be related to the property and content of ascorbic acid, which has the ability to neutralize DPPH. Phenolic compounds, mainly phenylpropanoids, may be a substrate for polyphenoloxidase (PPO), what can be connected with the enzymatic browning (Hisaminato et al. 2001). At the same time, this group of phenolic compounds has lower antioxidant properties. Therefore, objects grown at $100 \%$ RED and 90\% RED can be counted as those with the lower storage ability, because they accumulated highest amounts of phenylpropanoids. Phenolics in high concentrations increase the antioxidant properties in vitro on the one hand, but on the other it is not obvious whether recommending of a large amounts of polyphenolics in foods is beneficial due to their pro-oxidative properties (Halliwell 2007).

Weight loss of vegetables during storage may be result of water loss or increased respiration (Paull 1999; Nicola et al. 2004). In this study, decrease in lamb's lettuce fresh weight during storage was also observed, but it was not resulted from light source during growth. A lack of dry weight increase excludes a drastic loss of water through the storage.

Chlorophylls content in lamb's lettuce leaves decreased in our experiment with the length of storage. Spinardi \& Ferrante (2012) reported that content of chlorophylls did not change during 14-daystorage of baby leaf lettuce at $4{ }^{\circ} \mathrm{C}$ in darkness. Also study of Spinardi et al. (2010) showed lack of significant chlorophylls changes in both spinach and baby leaf lettuce leaves after one week of storage at $4{ }^{\circ} \mathrm{C}$ and in darkness. In contrary, in Ferrante \& Maggiore (2007) study, chlorophylls contents significantly decreased in lamb's lettuce leaves after 8 days of storage at $4{ }^{\circ} \mathrm{C}$ and in darkness from about 1.8 to $1.5 \mu \mathrm{g} \cdot \mathrm{mg}^{-1}$ f.w. Decrease of carotenoids content was from 21 to $19 \mu \mathrm{g} \cdot \mathrm{mg}^{-1} \mathrm{f}$.w. Contents of both pigments remained at similar level during second week of storage. Effect of different light source used during lamb's lettuce cultivation on chlorophylls and carotenoids content was not observed in our study.

According to Panda \& Sarkar (2013) among the different chlorophyll $a$ fluorescence parameters, the Performance Index ( $\mathrm{PI}_{\mathrm{ABS}}$ ) could be used with a greater accuracy to estimate leaf senescence of rice. In our study both fluorescence parameters, $\mathrm{Fv} / \mathrm{Fm}$ and $\mathrm{PI}_{\mathrm{ABS}}$, decreased gradually during 3 weeks of storage of lamb's lettuce similarly as in Ferrante \& Maggiore (2007) study in which lamb's lettuce was stored at $10{ }^{\circ} \mathrm{C}$ for 15 days. In our study, no significant effect of light source during growth in the greenhouse on the value of $\mathrm{Fv} / \mathrm{Fm}$ was observed. The only negative effect after three weeks of storage was found on plants grown under HPS lamps and 50\% RED LEDs that had lower $\mathrm{PI}_{\mathrm{ABS}}$ values than those grown at higher share of red light.

\section{CONCLUSIONS}

Quality and ability to storage of Valerianella locusta plants cultivated under LED lamps emitting light of different red/blue spectrum was at least as good as of plants cultivated under HPS lamps.

\section{Acknowledgements}

This study was supported by the National Science Centre in Poland (Project No 2011/01/B/NZ9/00058).

The authors thank to Mr. Piotr Strzetelski for the help with the plant cultivation.

\section{REFERENCES}

Ferrante A., Maggiore T. 2007. Chlorophyll a fluorescence measurements to evaluate storage time and temperature of Valeriana leafy vegetables. Postharvest Biol. Technol. 45: 73-80. DOI: 10.1016/j.postharvbio.2007.02.003.

Fukumoto L., Mazza G. 2000. Assessing antioxidant and prooxidant activities of phenolic compounds. J. Agric. Food Chem. 48(8): 3597-3604. DOI: 10.1021/jf000220w. 
Halliwell B. 2007. Dietary polyphenols: good, bad, or indifferent for your health? Cardiovascular research 73(2): 341-7. DOI: 10.1016/j.cardiores.2006.10.004.

Hisaminato H., Murata M., Homma A. 2001. Relationship between the enzymatic browning and phenylalanine ammonia-lyase activity of cut lettuce, and the prevention of browning by inhibitors of polyphenol biosynthesis. Biosci. Biotechnol. Biochem. 65(5): 1016-1021.

Hogewoning S.W., Trouwborst G., Maljaars H., Poorter H., van Leperen W., Harbinson J. 2010. Blue light dose-responses of leaf photosynthesis, morphology, and chemical composition of Cucumis sativus grown under different combinations of red and blue light. J. Exp. Bot. 61(11): 3107-3117. DOI: 10.1093/jxb/erq132.

Jung E.S., Lee S., Lim S.H., Ha S.H., Liu K.H., Lee C.H. 2013. Metabolite profiling of the short-term responses of rice leaves (Oryza sativa cv. Ilmi) cultivated under different LED lights and its correlations with antioxidant activities. Plant Science 210: 61-69. DOI: 10.1016/j.plantsci.2013.05.004.

Klamkowski K., Treder W., Treder J., Puternicki A., Lisak E. 2012. Wpływ doświetlania lampami sodowymi i LED na aktywność fotosyntetyczną oraz wzrost roślin pomidora. Prace Instytutu Elektrotechniki 256: 75-86. [in Polish]

Li Q., Kubota C. 2009. Effects of supplemental light quality on growth and phytochemicals of baby leaf lettuce. Environmental and Experimental Botany 67: 59-64. DOI: 10.1016/j.envexpbot.2009.06.011.

Lichtenthaler H.K., Babani F. 2004. Light adaptation and senescence of the photosynthetic apparatus. Changes in pigment composition, chlorophyll fluorescence parameters and photosynthetic activity. In: Papageorgiou G.C., Govindjee (Eds.), Chlorophyll a Fluorescence: A Signature of Photosynthesis. Advances in Photosynthesis and Respiration, Springer, Dordrecht 19: 713-736.

Martyniak-Przybyszewska B. 2005. Yields of leaf beet (Beta vulgaris L. var. cicla L.) and lamb's lettuce (Valeiranella olitoria L.) grown in Olsztyn. Scientific works of the Lithuanian Institute of Horticulture and Lithuanian University of Agriculture. Horticulture and Vegetable Growing 24(3): 196-200.
Massa G.D., Kim H.H., Wheeler R.M., Mitchell C.A. 2008. Plant productivity in response to LED lighting. HortScience 43(7): 1951-1956.

Michalak A. 2006. Phenolic compounds and their antioxidant activity in plants growing under heavy metal stress. Pol. J. Environ. Stud. 15(4): 523-530.

Morrow R.C. 2008. LED lighting in horticulture. HortScience 43(7): 1947- 1950.

Nicola S., Hoeberechts J., Fontana E. 2004. Rocket (Eruca sativa Mill.) and corn salad (Valerianella olitoria L.): production and shelf-life of two leafy vegetables grown in a soilless culture system. Acta Hort. 633: 509-516.

Panda D., Sarkar R.K. 2013. Natural leaf senescence: probed by chlorophyll fluorescence, $\mathrm{CO}_{2}$ photosynthetic rate and antioxidant enzyme activities during grain filling in different rice cultivars. Physiol. Mol. Biol. Plants 19(1): 43-51. DOI: 10.1007/s12298-012-0142-6.

Paull R.E. 1999. Effect of temperature and relative humidity on fresh commodity quality. Postharvest Biol. Technol. 15(3): 263-277. DOI: 10.1016/S0925-5214(98)00090-8.

Péron J., Rees D. 1998. High-tech production of corn salad (Valerianella locusta (L) Laterr.), a local, French vegetable crop. Acta Hort. (ISHS) 467: 259-268.

Pekkarinen S.S., Stöckmann H., Schwartz K., Heinonen I.M., Hopia A.I. 1999. Antioxidant activity and partitioning of phenolic acids in bulk and emulsified methyl linoleate. J. Agric. Food Chem. 47: 3036-3043.

Samoulienė G., Sirtautas R., Brazaitytė A., Duchovskis P. 2012. LED lighting and seasonality effects antioxidant properties of baby leaf lettuce. Food Chemistry 134: 1494-1499. DOI: 10.1016/j.foodchem.2012.03.061.

Sharma O.P., Bhat T.K. 2009. DPPH antioxidant assay revisited. Food Chemistry 113(4): 1202-1205. DOI: 10.1016/j.foodchem.2008.08.008.

Spinardi A., Cocetta G., Baldassarre V., Ferrante A., Mignani I. 2010. Quality changes during storage of spinach and lettuce baby leaf. Acta Hort. 877: 571-576.

Spinardi A., Ferrante A. 2012. Effect of storage temperature on quality changes of minimally processed baby lettuce. J. Food Agric. Environ. 10(1): 38-42. 
Strasser R.J., Tsimilli-Michael M., Srivastava A. 2004. Analysis of the chlorophyll a fluorescence transient. In: Papageorgiou G.C., Govindjee (Eds.), Chlorophyll a Fluorescence: A Signature of Photosynt-hesis. Advances in Photosynthesis and Respiration Springer, Dordrecht 19: 321-362.

Trouwborst G., Oosterkamp J., Hogewoning S.W., Harbinson J., van Ieperen W. 2010. The responses of light interception, photosynthesis and fruit yield of cucumber to LED-lighting within the canopy. Physiol. Plant. 138(3): 289-300. DOI: 10.1111/j.13993054.2009.01333.x.
Wellburn A.R. 1994. The spectral determination of chlorophylls a and $b$, as well as total carotenoids, using various solvents with spectrophotometers of different resolution. J. Plant Physiol. 144(3): 307-313. DOI: $10.1016 / \mathrm{S} 0176-1617(11) 81192-2$.

Wills R., McGlasson B., Graham D., Joyce D. 1998. Postharvest. An introduction to the physiology and handling of fruit, vegetables and ornamentals. 4th edition, UNSW Press.CAB International, $262 \mathrm{p}$. 